\title{
SHIITAKE PRODUCTION IN CORNCOB SUBSTRATES
}

\author{
FREDERICO CASTILHO DA EIRA ${ }^{1}$; WALTER FERNANDES MEIRELLES ${ }^{2}$; LUZIA DORETTO \\ PACCOLA - MEIRELLES ${ }^{3}$ \\ Universidade Estadual de Londrina, Caixa Postal 6001, 86051-990 Londrina/PR, Brasil. ${ }^{1}$ CCA, Departamento de \\ Agronomia, e-mail:fred_eira@msn.com, ${ }^{3}$ CCB, Departamento de Biologia, e-mail: paccola@uel.br \\ ${ }^{2}$ Embrapa Milho e Sorgo, Caixa Postal 151,35701-970 Sete Lagoas/MG,Brasil.e-mail: walter@cnpso.embrapa.br
}

Revista Brasileira de Milho e Sorgo, v.4, n.2, p.141-148, 2005

\begin{abstract}
Lentinula edodes (shiitake mushroom) is an edible mushroom of world importance that has been cultivated for thousands of years, first in China and then in Japan. Besides the ability to convert lignocellulosic materials into food with good flavor and texture, it also has medicinal properties and nutritional benefits to human health, that places it at the forefront of cultivated mushrooms. In Brazil shiitake cultivation currently most used is on logs of Eucalyptus species. Another method used for shiitake production is the synthetic bags cultivation, where the sawdust is the basic ingredient and more used in the formulations of substrate. This method has been shown to be a promising alternative in the conversion of agricultural and agro-industrial residues into highly nutritional food. So, other lignocellulosic residues, as straws and sugar cane pulp, and corncobs have potential to be used to shiitake cultivation. In the present study, $L$. edodes was inoculated in substrates based on ground corncob in the following combinations: 1) corncob (90\%) + rice bran $(10 \%)$; 2) corncob (45\%) + eucalyptus sawdust $(45 \%)+$ rice bran $(10 \%) ; 3)$ corncob $(50 \%)+$ eucalyptus sawdust $(50 \%) ; 4)$ corncob $(100 \%)$. The substrates were placed in polypropylene bags $(1.5 \mathrm{Kg}$ substrate/bag) and autoclaved for $90 \mathrm{~min}$ at $120^{\circ} \mathrm{C}$. Good mushroom production was observed in all treatments with greatest yield in combination 1. L. edodes cultivation was also assessed in whole corncob substrates (commercial corncobs and popcorn corncobs). The corncobs were tied into blocks, boiled in water and placed in polypropylene bags. From this cultivation methodology originated small mushrooms, a characteristic of commercial interest for the conserve industry and for specific markets that require different mushrooms patterns for commercialization. Corncobs, both ground and whole, can be an alternative for shiitake mushroom production from agricultural residue.
\end{abstract}

Key words: shiitake, biological efficiency, agricultural residues, synthetic cultivation

\section{PRODUÇÃO DE SHIITAKE EM SUBSTRATOS À BASE DE SABUGO DE MILHO}

RESUMO - Lentinula edodes (shiitake) é um cogumelo comestível de importância mundial e seu cultivo é milenar, primeiramente na China e, depois, no Japão. Além da capacidade de converter materiais lignocelulósicos em alimento de sabor e textura apreciados, também possui propriedades medicinais e nutricionais benéficas à saúde humana, o que o coloca em destaque frente a outros cogumelos cultivados. A forma de cultivo de shiitake mais utilizada no Brasil é a produção em toras de madeira, sendo as espécies de Eucalyptus as mais usadas. O cultivo sintético é outro método de produção, no qual 
a serragem é o ingrediente básico e mais utilizado nas formulações de substratos. Esse método representa uma alternativa promissora na conversão de resíduos agrícolas e agroindustriais em alimento de alta qualidade nutricional. No entanto, outros resíduos lignocelulósicos, como palhas e bagaço de cana, são também apropriados para o cultivo do shiitake. No presente estudo, L. edodes foi inoculado em substratos à base de sabugo de milho triturado, nos seguintes combinações: 1) sabugo triturado $(90 \%)+$ farelo de arroz $(10 \%)$; 2) sabugo triturado $(45 \%)+$ serragem de Eucalipto $(45 \%)+$ farelo de arroz $(10 \%)$; 3) sabugo triturado $(50 \%)+$ serragem de eucalipto $(50 \%)$; 4) sabugo triturado (100\%). Os substratos foram acondicionados em sacos de polipropileno $(1,5 \mathrm{Kg}$ de substrato/saco) e autoclavados durante $90 \mathrm{~min}$ a $120^{\circ} \mathrm{C}$. Em todos os tratamentos, foi observada produção do cogumelo com produtividade maior na combinação 1. Avaliouse também o cultivo de shiitake em substratos à base de sabugo de milho inteiro (sabugo de milho comercial e sabugo de milho pipoca). Os sabugos foram amarrados em forma de blocos, fervidos em água e acondicionados em sacos de polipropileno. Foi observada a formação de cogumelos pequenos, característica desejável para a indústria de conservas e para mercados específicos, que exigem diferentes padrões de comercialização. $\mathrm{O}$ sabugo de milho, tanto triturado como inteiro, representa um substrato apropriado e alternativo para o cultivo do cogumelo comestível shiitake.

Palavras chave: shiitake, eficiência biológica, resíduos agrícolas, cultivo sintético

Lentinula edodes (Berk.) Pegler, known as shiitake mushroom, is an alternative to increase the offer of proteins in the human diet. This mushroom can develop and convert lignocellulosic biomass into nutritive and tasty foods (Przybylowicz \& Donoghue, 1990).

Shiitake is traditionally produced on cut logs, a method developed in Japan in the 1940s (Singer, 1961). In Brazil, different species of the Eucalyptus genus are used as bed logs for shiitake production. An alternative method of shiitake cultivation, the synthetic log cultivation, was developed in Taiwan, in the 1980s, using sawdust as the primary substrate ingredient to which supplementary nutrients were added to promote and accelerate fungus growth (Hiromoto, 1991). Nutritional supplementation aims to increase the levels of nitrogen and carbohydrates, resulting in readily available sugars and other nutrients. The supplements used in the substrate accelerate the initial mycelial growth and increase mushroom production. Rice and wheat bran and some sources of calcium are important supplements (Stamets, 2000). The main advantages of using synthetic medium over natural logs are the reduction of period of time for mushroom production and the increasing biological efficiency (Eira \& Montini, 1997). The cycle for synthetic medium cultivation is approximately 4 months, from inoculation to harvest. Biological efficiencies for this method average from 75 to $125 \%$. In contrast, maximum efficiencies of $33 \%$ are obtained in the natural log (Royse, 1997), and it is necessary about 6 months for the first fluxe. The fungus goes through the same development stages in the different forms of shiitake cultivation, both on $\log s$ and in synthetic $\log$ cultivation: inoculation, incubation, induction, followed by fructification (production) and rest (Przybylowicz \& Donoghue, 1990).

Agricultural residues rich in cellulose, hemicellulose and lignin combined or not with sawdust are alternative substrates that should be exploited for commercial shiitake cultivation. 
Thus, considering the availability of corncobs in Brazil, the objective of this study was to assess shiitake production in corncob supplemented or not with rice bran. This substrate was suitable for mycelial growth and for shiitake fructification.

\section{Materials and Methods}

L. edodes strains, culture medium and maintenance conditions of the strain: Shiitake's strain used was a commercial strain obtained from the Strain Bank at the Genetics of Microorganisms Laboratory at CCB-UEL/ Londrina/ PR/Brazil. The strain was cultivated in PDA (Potato Dextrose Agar) medium at $25^{\circ} \mathrm{C}$ and preserved in this medium.

Spawn: Sorghum (Sorghum bicolor) grains were imbibed in distilled water for $12 \mathrm{~h}$. The water was drained and $250 \mathrm{~g}$ of those grains were placed in $500 \mathrm{ml}$ flasks and autoclaved for $60 \mathrm{~min}$ at $120^{\circ} \mathrm{C}$. The grains were inoculated with three $5 \mathrm{~mm}$ agar disks containing shiitake mycelia. Spawn flasks were cultured at $23 \pm 2^{\circ}$ $\mathrm{C}$ for $15 \mathrm{~d}$ and shaken as needed to prevent mycelial knitting of the grains.

Substrates production: Two types of substrates for shiitake production were tested, ground corn cob and whole corn cob.

a) ground corncob: the corncobs were ground in a grinder with a fine mesh sieve and combined as follow: 1) ground corncobs (90\%) + rice bran $(10 \%), 2)$ ground corncobs $45 \%+$ eucalyptus sawdust (45\%) and rice bran (10\%), $3)$ ground corncobs $(50 \%)+$ eucalyptus sawdust $(50 \%)$ and 4$)$ ground corncobs $(100 \%)$.

Distilled water was added, to each substrate combination, until complete hydration. The substrates were placed into polypropylene plastic bags containing a gas exchange filter (1.5 $\mathrm{kg}$ substrate/bag) and autoclaved for $90 \mathrm{~min}$ at $120^{\circ} \mathrm{C}$. Each treatment consisted of five replications. The weight of the dry substrate was determined and was used to determine the biologic efficiency (BE) of the strain (fresh weight of mushrooms produced x 100/dry weight of substrate).

b) whole corncobs: Two types of corncob were assessed: popcorn corncobs and commercial corncobs. The corncobs were grouped in blocks (10 units of commercial corncobs and 18 units of popcorn corncobs) and tied. The blocks were boiled for 15 minutes in distilled water, placed in polypropylene bags with a gas exchange filter and sterilized in autoclave for 90 minutes at $120^{\circ} \mathrm{C}$. The substrates were inoculated under aseptic conditions, using approximately $15 \mathrm{~g}$ spawn distributed on the substrate surface. The inoculated substrates were transferred to a mycelial growth room at $24 \pm$ $3^{\circ} \mathrm{C}$ with continuos light.

\section{Fructification conditions:}

a) Fructification on ground corncobs: After mycelial run, the plastic bags were removed from the blocks which were submitted at $3^{\circ} \mathrm{C}$ temperature (thermic shock) for approximately $24 \mathrm{~h}$. Afterwards, the blocks were transferred to production chamber with humidity $80 \%$, at environmental temperature $\left(22-25^{\circ} \mathrm{C}\right)$.

In the second production flush, the blocks were submersed into water ( 5 degrees below the environmental temperature) for $24 \mathrm{~h}$ and replaced on production chamber with humidity $80 \%$, at environmental temperature $\left(22-25^{\circ} \mathrm{C}\right)$.

b) Frutification on whole corncobs: The colonized blocks were submitted to thermal shock, using immersion in cold water ( 5 degrees below the environmental temperature) for $24 \mathrm{~h}$. The blocks were removed from the water and placed on a production chamber with humidity $80 \%$. 


\section{Results and Discussion}

\section{Shiitake mushroom production in substrates based on ground corncobs}

The first mushrooms production flush was observed 3 months after inoculation (Figure 1). The blocks were submitted to three production flushes where the mean yield (fresh mass), the number, the dry mass, and biological efficiency of the treatments were recorded. The mushroom yield from ground corncob substrates are shown in Table 1 and the Figure 2 shows the accumulated yield in the three production flushes.

Shiitake production was significantly greater in ground corncob added with rice bran (treatment 1), which supported a greater number of mushrooms, and there was no significant difference in size (fresh mass/mushroom) compared to other combinations. Corncob added

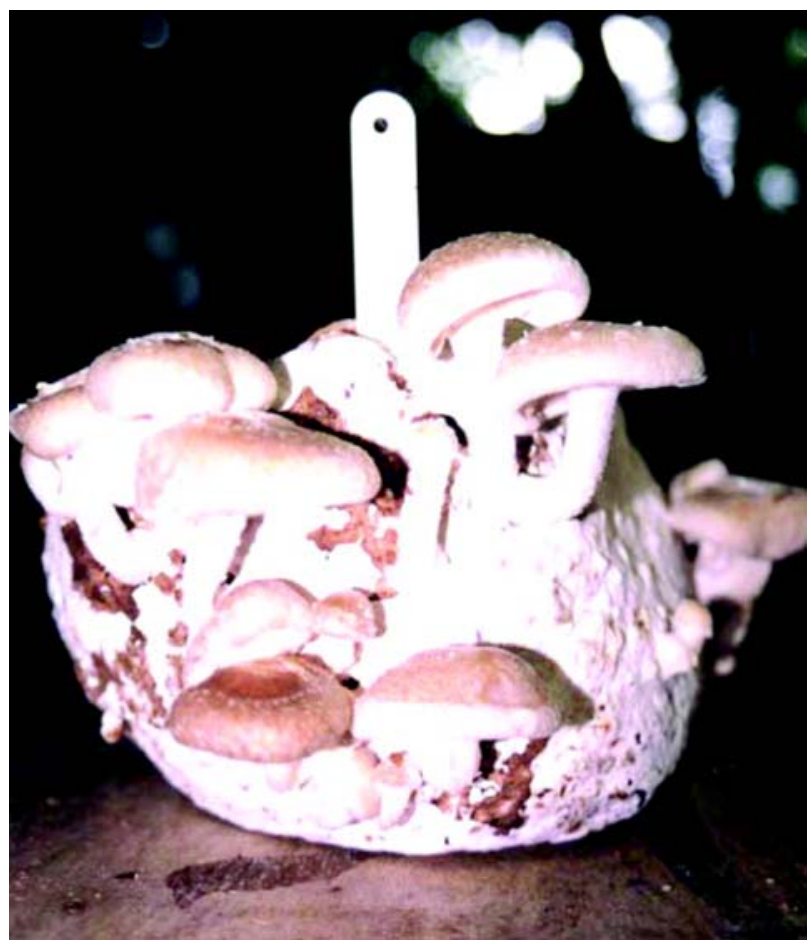

FIGURE 1: Shiitake production in ground corncob substrate after 90 days of incubation

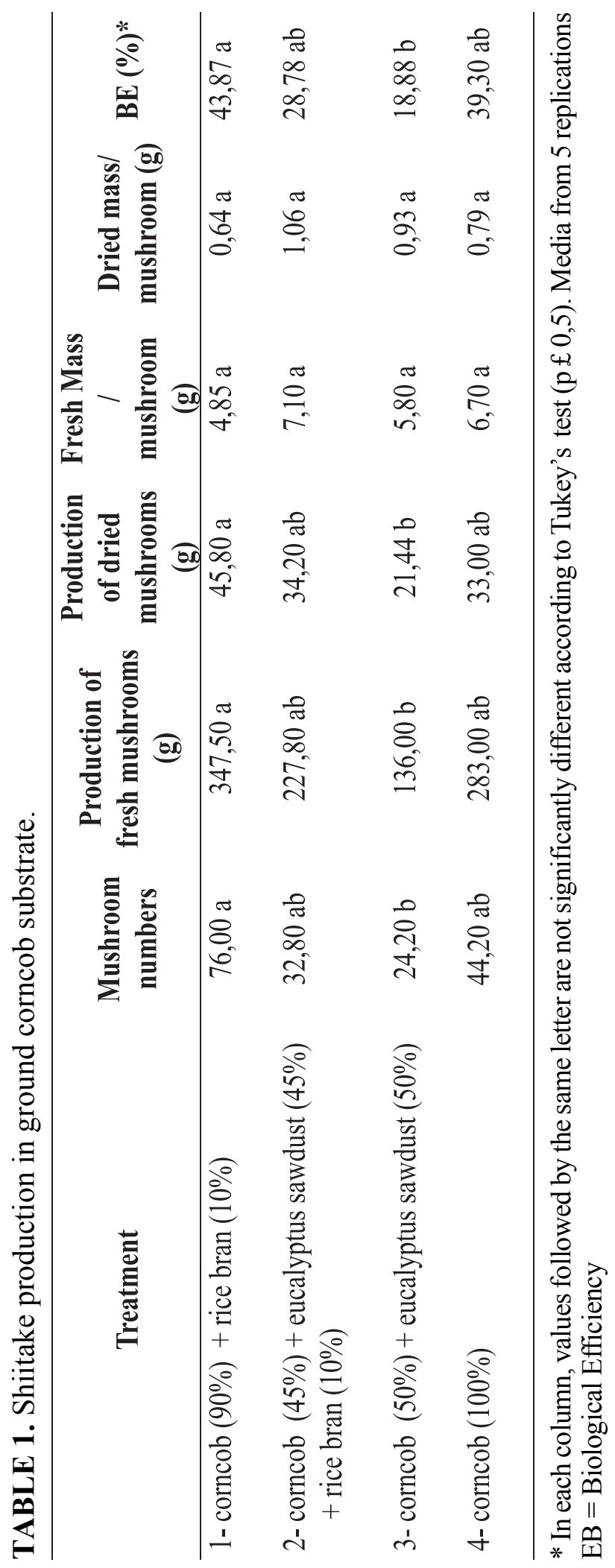


with sawdust in the proportion used was not The biological efficiency observed in the suitable for shiitake production, once the combinations 1 and 4 is similar to that observed biological efficiency of these substrates was low in other strains used in Brazil, in other substrates when compared with other production substrates. (Rossi et al., $2003 \mathrm{a}, \mathrm{b}$ ).

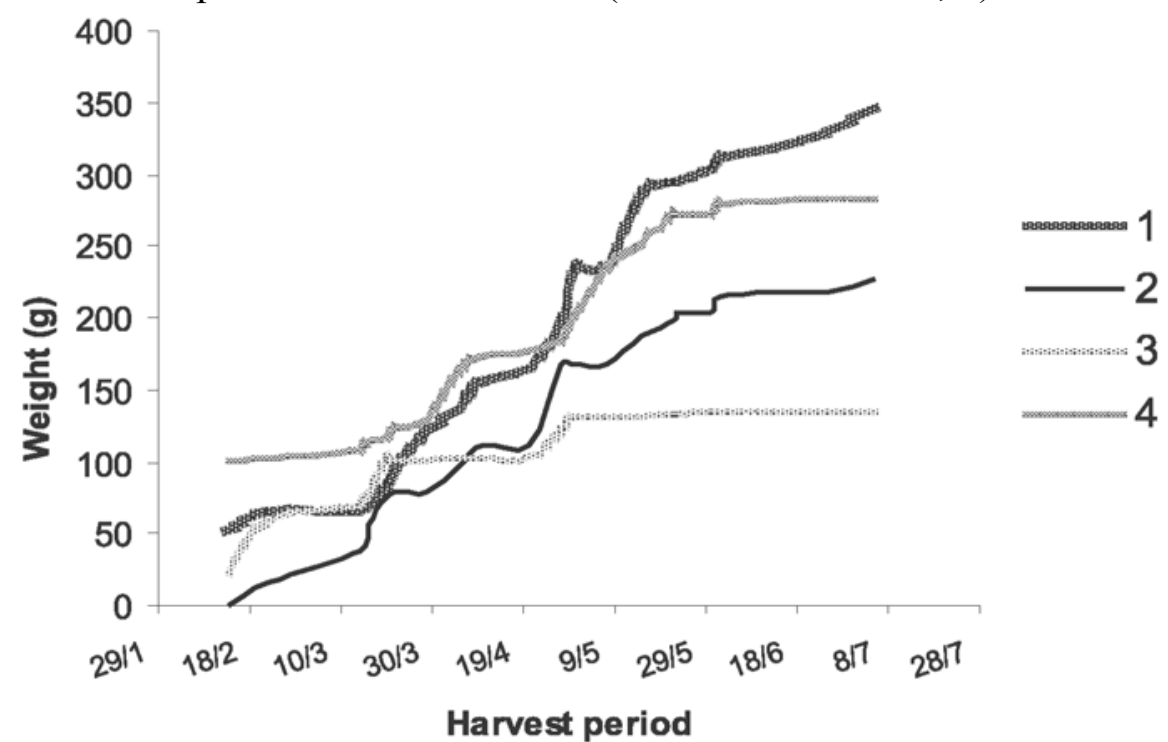

FIGURE 2. Accumulated production of shiitake mushrooms (fresh weight)

1) corncob $(90 \%)+$ rice bran $(10 \%) ; 2)$ corncob $(45 \%)+$ eucalyptus sawdust $(45 \%)+$ rice bran $(10 \%) ; 3)$ corncob $(50 \%)+$ eucalyptus sawdust $(50 \%) ; 4)$ corncob $(100 \%)$

The accumulated production, expressed to the dry weight of the mushrooms, was also greater in the corncob added rice bran (Figure 3) compared to other combinations.

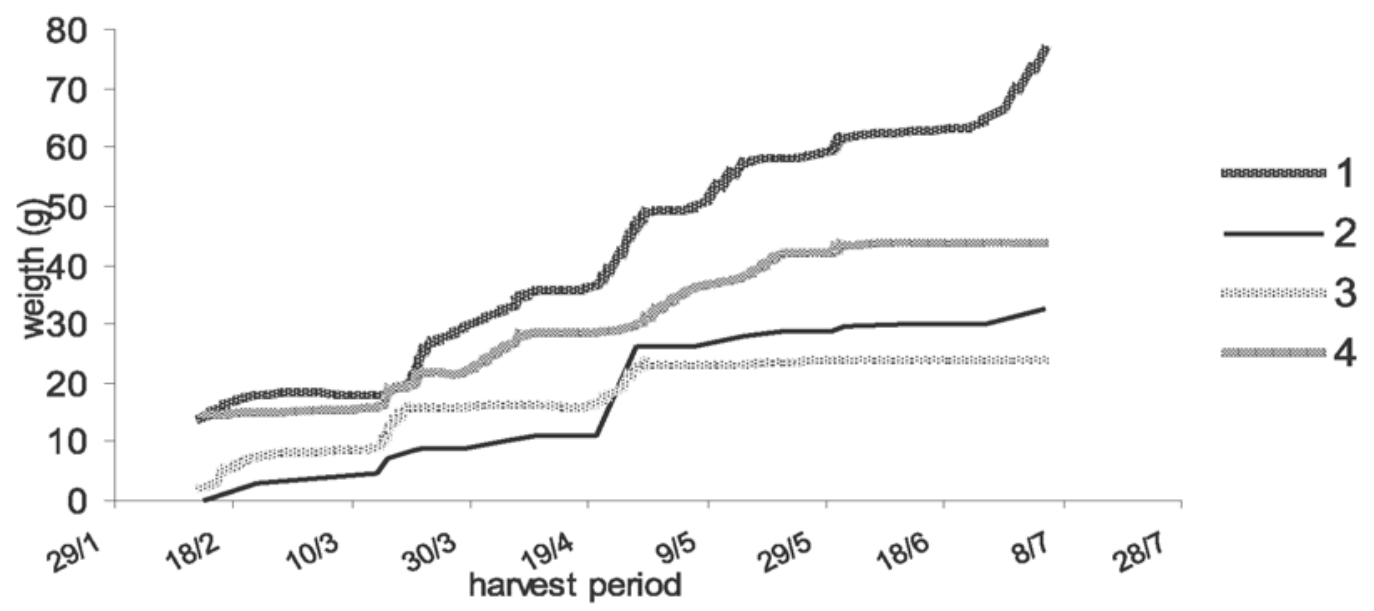

FIGURE 3. Accumulated production of shiitake mushrooms (Dried weight)

1) corncob $(90 \%)+$ rice bran $(10 \%) ; 2)$ corncob $(45 \%)+$ eucalyptus sawdust $(45 \%)+$ rice bran $(10 \%) ; 3)$ corncob $(50 \%)+$ eucalyptus sawdust $(50 \%) ; 4)$ corncob $(100 \%)$ 
Basidiocarp diameter was very similar for the mushrooms produced in all substrate combination (Table 2), although the total fresh mushrooms production had been different (Table 1).

The stem or stalk size can vary according to the light intensity (Ishikawa, 1967; Przybylowicz and Donoghue, 1990). Environments with little light available, such as in the present study, produce etiolated mushrooms (Table 2). This is an economically undesirable characteristic.

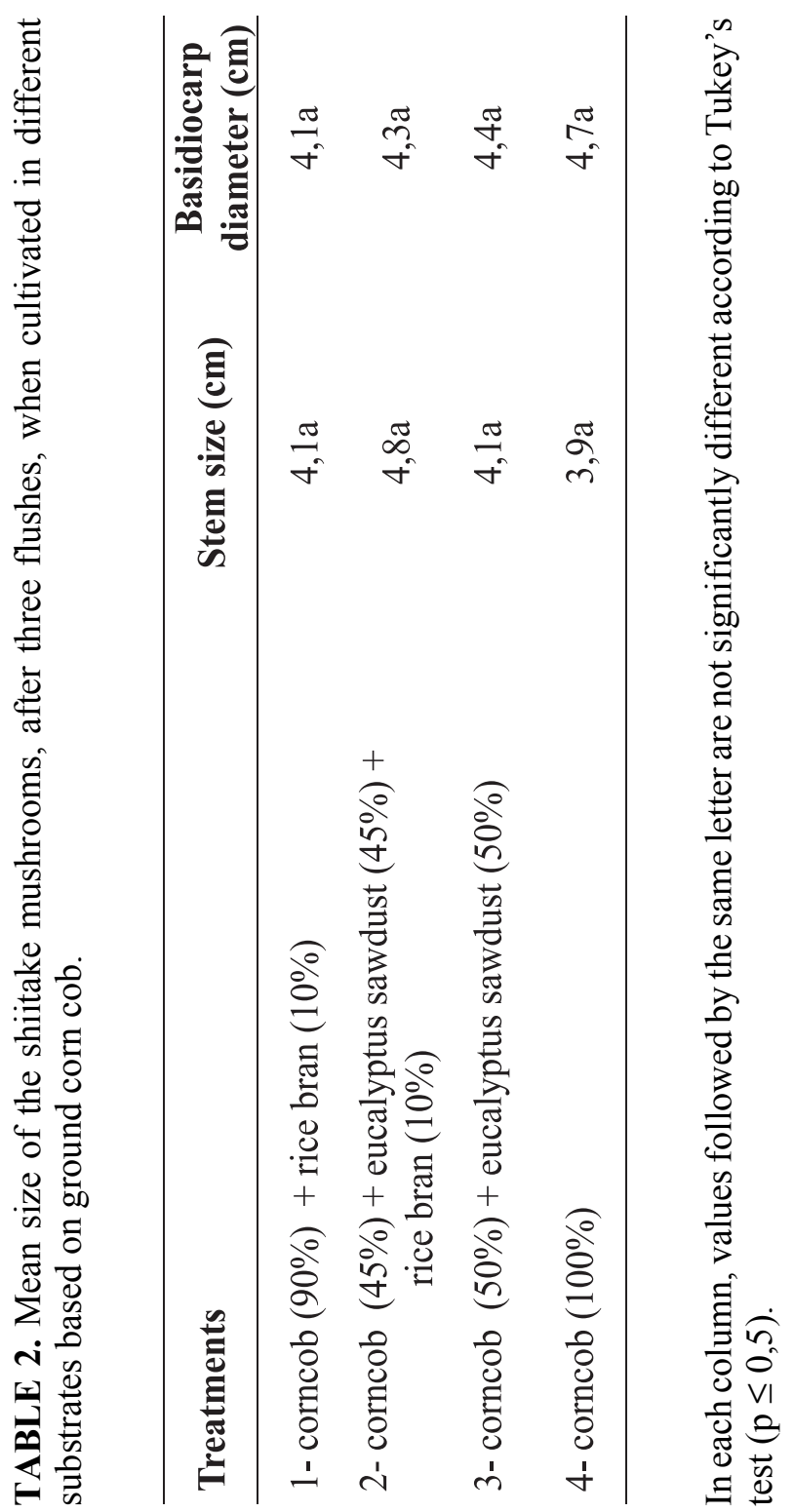

\section{Shiitake production on whole corncob substrates}

Although the yield was verified only in the first flush, the whole popcorn and normal corncobs were suitable for shiitake production (Figure 4). The total yield (fresh weight) of 10 replications on the whole normal and popcorn corncobs was $44.6 \mathrm{~g}$ and $26.3 \mathrm{~g}$ respectively.

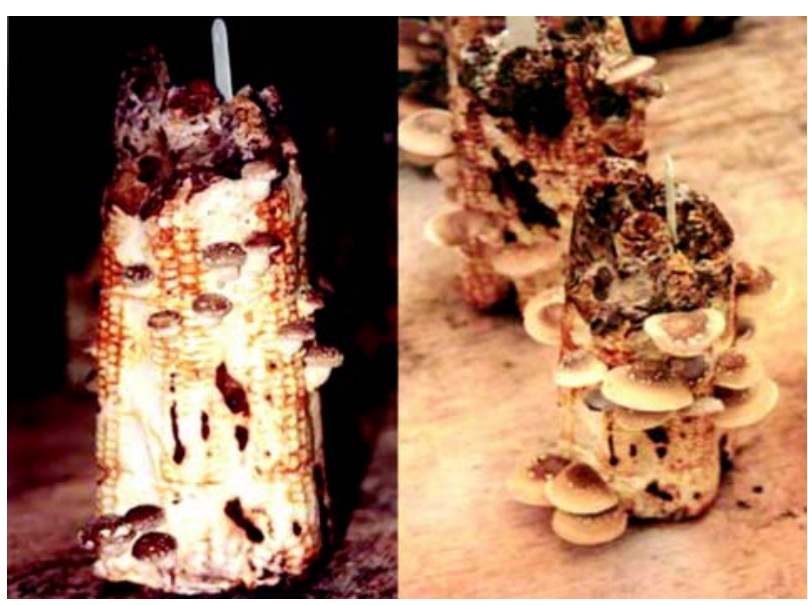

FIGURE 4. (left) Young mushrooms with closed basidiocarp; (right) Mature mushrooms with open basidiocarp growing in corncob.

The experimental conditions of temperature and moisture were unsuitable, and there was water loss from the blocks to the environment that probably contributed not to occur the $2^{\text {nd }}$ flush of production. According to Przybylowcz \& Donoghue (1990), there should be periodic additional flushes after the $1^{\text {st }}$ flush without need later induction, if conditions for good fructification are maintained. Nutrient supplementation in the water used to give the thermic shock may be a good option to increase the yield (Han et al., 1981).

This cultivation methodology gives rise to small mushrooms (Figure 4; Table 3), a characteristic of commercial interest for the conserve industry and for specific markets that require different mushroom patterns for commercialization. 
TABLE 3. Mean stem size and mean basidiocarp diameter shiitake mushrooms produced on commercial and popcorn corncobs (whole corn cobs). Means from 20 mushrooms

Treatments

Mean stem length (cm)
Mean basidiocarp diameter (cm)

\begin{tabular}{lcc}
\hline Commercial corncobs & 2,1 & 3,3 \\
Popcorn corncobs & 1,8 & 3,4 \\
\hline
\end{tabular}

In other countries, as Japan, China and the USA, this agricultural residue has been commercially used for mushrooms production. Morales et al. (2000) described the cultivation of Auricularia fuscosuccinea in corncob substrates combined with coffee pulp in the proportion of $75 \%$ corncob: $25 \%$ coffee pulp. Hyspizygus marmoreus, the bunashimeji, is another species cultivated on ground corncobs and commercialized on large scale in Japan. Some Pleurotus species have been produced in substrates based on agricultural residues such as corncob, sugar cane bagasse, coffee residues, palm leaves and cereal straw (Stamets, 2000). Energy and food problems are worsening on the planet because of the constant and accentuated population increase. Thus the use of agricultural residues as substrate for food production will be a viable alternative within a few decades. If the straw, produced in the field was properly used for this purpose, millions of tons of mushrooms could be produced for human food and millions of tons of agricultural fertilizers would result from the decomposition of this straw which would be a benefit for agriculture (Chang, 1980).

\section{Conclusions}

Ground corncobs supplemented with rice bran, is a viable alternative as substrate for cultivation of the shiitake mushroom. The whole popcorn and normal corncobs were also suitable for shiitake production.

Corncobs, both ground or whole, are a promising alternative for shiitake mushroom production.

\section{Literature Cited}

CHANG, S. T. Mushrooms as human food. BioScience, Washington, v. 30, p. 399-401, 1980.

EIRA, A. F.; MONTINI, R. M. C. Manual de cultivo do shiitake (Lentinula edodes (Berk.) Pegler). Botucatu: FEPAF; FCA-UNESP, 1997. $38 \mathrm{p}$.

HAN, J. H.; YENG, W. T.; CHIEN, L. C.; CHANG, S. Physiology and ecology of Lentinus edodes (Berk.). Sing. Mushroom Science, Sidney, v. 2, p. 623-658, 1981.

HIROMOTO, B. T. Comparative analysis of shiitake culture systems. In: MAHER, M. J. (Ed.). Science and cultivation of edible fungi. Rotterdam: Balkema, 1991. p. 489- 496.

ISHIKAWA, H. Physiological and ecological studies on Lentinus edodes (Berk.) Sing. Journal of Agriculture Laboratory, Japan, v. 8, p. 1-53, 1967. 
MORALES, G. E.; HUERTA-PALACIOS, G.; SÁNCHEZ-VÁZQUEZ, J. E. Production technology optimization for Auricularia fuscosuccinea. In: GRIENSVEN, L. J. L. D. van (Ed.). Science and cultivation of edible fungi. Rotterdam: A. A. Balkema, 2000. p. 943-948.

PRZYBYLOWICZ, P.; DONOGHUE, J. Shiitake Growers handbook: the art and science of mushroom cultivation. Kendall: Hunt Publishing, 1990. 217 p.

ROSSI, I. R.; MONTEIRO, A. C.; MACHADO, J. O.; BARBOSA, J. C. Supplementation of sugarcane bagasse with rice bran and sugarcane molasses for shiitake (Lentinula edodes) spawn production. Brazilian Journal of Microbiology, São Paulo, SP, v. 34, p. 61-65, 2003 (a)

ROSSI, I. R.; MONTEIRO, A. C.; MACHADO, J. O.; BARBOSA, J. C.; ANDRIOLI, J. L. Shiitake (lentinula edodes) production on a sterilized bagasse substrate enriched with rice bran and sugarcane molasses. Brazilian Journal of Microbiology, São Paulo, SP, v. 34, p. 66-71, 2003 (b).

ROYSE, D. J. Specialty mushrooms and their cultivation. Horticultural Review, New York, v. 19, p. 59- 97, 1997.

STAMETS, P. Growing gourmet and medicinal mushrooms. Berkeley: Ten Speed Press, 2000. 592 p. 